\title{
Relationship Marketing in Tertiary Education: Empirical Study of Relationship Commitment and Student Loyalty in Hong Kong
}

\author{
Wong $\mathrm{H}^{1}$, Wong $\mathrm{R}^{2}$, Leung $\mathrm{S}^{1}$ \\ ${ }^{1}$ The Hong Kong Polytechnic University, Hong Kong \\ ${ }^{2}$ The Chinese University of Hong Kong, Hong Kong \\ Correspondence: Wong H, The Hong Kong Polytechnic University, Kowloon, Hong Kong. \\ Received: November 6, 2017 \\ Accepted: January 23, 2018 \\ Online Published: January 26, 2018 \\ doi:10.5539/ibr.v11n2p205 \\ URL: https://doi.org/10.5539/ibr.v11n2p205
}

\begin{abstract}
This study attempts to investigate the applicability of relationship marketing concepts in the private tertiary education industry. With the rapid growth of tertiary education and new academic structure in Hong Kong, it is interesting to investigate the relationship between relationship commitment and student loyalty, and the key determinants of relationship commitment, in a leading private tertiary education institution in Hong Kong. Questionnaires were designed to collect data, and structural equation modeling approach was adopted to evaluate the explanatory power and casual links of the model. The results indicate that relationship commitment is a driver of student loyalty. Relationship benefits and trust are found to have positive influence on relationship commitment. Relationship termination costs and shared values are found to have non-significant roles in determining relationship commitment in private tertiary education environment, while shared value has a significant positive impact on trust. The research provides new insights to the management of private tertiary education providers in building relationship with students and resources allocation. The study discusses the implications of the findings and suggests areas for future research.
\end{abstract}

Keywords: relationship marketing, private tertiary education, student loyalty, relationship commitment

\section{Introduction}

Tertiary education is essential for a society's development. The role of tertiary education is widely recognized globally. In addition to the public tertiary education, there has been a vigorous development of private tertiary education (PTE) in the past recent decades. Since PTE institutions are receiving minimal or no government funding, students have to pay tertiary tuition fees for private tertiary education. In order to enhance the admission to PTE, many countries have successfully introduced different student loan schemes for postponing the costs of education until after graduation. Demand for tertiary education has been boosted and rapid growth in PTE resulted.

Due to the fast-developing self-financing post-secondary education and the trend of young couples having fewer children, more opportunities exist for higher secondary school graduates to enter tertiary educational institutions and thus private educational institutions are facing keen competition in recruiting and retaining students. It is a great challenge for them to generate sufficient revenues for running the institutions in the competitive education market.

Building relationship with customers is crucial for business to sustain competitive advantages (Wong and Sohal, 2002). Relationship marketing benefits both the customer and firm. Firms can be benefited in retaining customers and attracting new customers (Berry, 1995). Retaining customers and keeping them loyal is significant to service industry (Pritchard et al., 1997). Benefits of having continued customer loyalty to the organization are well understood (Berry and Parasuraman 1991; Reichheld and Sasser 1990; Reichheld 1993).

Commitment has positive effect and enhances the desire of the students to continue in the school till graduation. Commitment can be increased by enhancing the level of trust with the students. (Adidam et al., 2004). Developing student loyalty is important for tertiary educational institutions to seek for financial sustainability (Carvalho and de Oliveira Mota, 2010).

\section{Education in Hong Kong}

In view of the change to a knowledge-based economy, the Hong Kong Government attaches great importance to 
the development of tertiary education in order to equip and upgrade young people to contribute to society. To cater for Hong Kong's strong intention to become a regional education hub, comprehensive reviews and reforms on tertiary education have been carried out in Hong Kong since the 1990s. In addition to the publicly-funded programmes offered by the local universities, PTE emerged.

Over the past decades, students were required to attempt the Hong Kong Certificate of Education Examination (HKCEE) upon completion of five-year secondary education which acted as a filter for the students to attempt the (Hong Kong Advanced Level Examination) HKALE upon completion of the two-year higher secondary education before being admitted to the three-year undergraduate programmes.

A new academic structure "3-3-4" Scheme for senior secondary education and tertiary education in Hong Kong has started from the school year 2009/10. It is different from the old curriculum as having completed the three-year junior secondary education, students will receive three years of senior secondary education and attempt the new Hong Kong Diploma of Secondary Education (HKDSE), a prerequisite to being eligible to receive the four years of university education.

Since 2012, the HKDSE under the New Senior Secondary (NSS) curriculum and assessment of the new academic structure has replaced HKCEE and HKALE and prepared students for entering university after their secondary school education.

Under the NSS curriculum, students of HKDSE are one year younger than the students of HKALE, and the students of HKDSE only have to take one public examination whereas students of the HKALE have to take two public examinations before entering the tertiary education. It is in general believed that the students of HKALE are more mature and tough than students of HKDSE.

In light of providing young people more opportunities to access to tertiary education, it is the government's policy to strive for the parallel development of the publicly-funded and PTE sectors. There has been a rapid expansion in the PTE sector. In the past ten years from 2005 to 2015, the number of full-time accredited private tertiary programmes has increased by $67 \%$ from 273 to 455 , including a rise in the number of full-time private bachelor degree programmes by $213 \%$ from 40 to 125 with flexible study pathways of multiple entry and exit points. The number of student enrolments in PTE after completion of secondary level also increased by $67 \%$ from 36,922 to 61,582 (iPASS). The ratio of tertiary to secondary students increased from $62.7 \%$ in $2010 / 11$ to $88.2 \%$ in 2015/16 (EDB). The PTE sector has been facing keen competition with the increase in supply in the past few years.

Because of the changes in the background of students entering tertiary education and the rapid growth in the PTE sector, it is worthwhile to study the applicability of relationship marketing in private tertiary education environment. Based on Morgan and Hunt's model (1994) in relationship marketing perspective, the objectives of this study are to investigate relationship benefits, relationship termination costs, shared values and trust, as the four key factors affecting the relationship commitment, and examine the effect of relationship commitment on student loyalty in the PTE context in Hong Kong.

\section{Literature Review}

\section{Relationship Marketing}

Relationship marketing was first introduced in the services marketing literature by Berry as "attracting, maintaining and in multi-service organizations - enhancing customer relationships" (Berry, 1983, p. 25). The definition of relationship marketing presented by Gronroos is "to establish, maintain and enhance relationship with customers and other partners that are done by a mutual exchange and fulfilment of promises" (Gronroos, 1990, p.5). Harker (1999) examined the definitions of relationship marketing and seven fundamental conceptual categories were identified.

Relationship marketing has a positive impact on customer loyalty (Berry, 1983, 1995; Alrubaiee and Al-Nazer, 2010; Firdaus and Kanyan, 2014). Commitment is a key factor contributes to the success of relationship marketing (Morgan and Hunt, 1994; Wu, Weng and Huang, 2012). With commitment, loyalty results and leads to long-term profitability (Miquel-Romero et al., 2014). For high-tech firms, relationship marketing is an effective strategy for enhancing partner loyalty and satisfaction (Wu, Weng and Huang, 2012).

\section{Relationship marketing in education context}

Relationship marketing in the PTE sector is defined as "a set of marketing activities or actions that attract, motivate, and enhance existing and potential students' relationships as well as students' parents, relatives, friends, reference groups for the benefit of all sides concerned, emphasizing on retaining existing students until their 
graduation, and attracting further students" (Al-Alak, 2006, p. 4). It is very important for the tertiary education sector to establish a high level of ability to attract, acquire and retain students until graduation (Al-Alak, 2006).

Perin et al. (2012) confirms Al-Alak's findings (2006) to attract and retain students by creating 'added value' for students that leads to student satisfaction and continued relationships. Tinto (1975) discussed the interaction between students and their tertiary educational institutions. It was suggested that student retention is directly affected by commitment and commitment is directly affected by the integration of students into the system of the educational institution and external commitments.

\section{Relationship Commitment}

Commitment is a concept from social psychology (Festinger, 1957; Kiesler, 1971; Kelley, 1983) applied to the field of marketing. Affective commitment has been studied in the context of relationship marketing (Morgan and Hunt, 1994; Kumar et al., 1995; Gundlach et al., 1995). It is an emotional commitment which reflects a psychological attachment to the partner (Geyskens et al., 1996; Bello and Gilliland, 2002; Sweeney and Swait, 2008). The continuance commitment reflects the need to maintain the relationship for avoiding perceived switching costs (Bansal and Taylor, 1999a, 1999b, Fornell, 1992; Ping, 1993, Jones et al., 2000; Sharma and Petterson, 2000). Normative commitment is the result that incorporates from the individual standards of his social environment (Dwyer et al., 1987; Heide and John, 1992; Gundlack and Murphy, 1993). The commitment, particularly affective commitment is an essential factor in the development of customer relationship loyalty (Amani, 2015).

\section{Relationship commitment in education context}

Commitment refers to how much the students' abilities, skills, and value system fits the university's expectations, demands, and values (Rojas-Méndez et al., 2009).

Commitment as a drive to loyalty (Fournier, 1998; Sheth \& Parvatiyar, 1995) has been applied to academic institutions (Perin et al., 2012). Institutional commitment is positively associated with student retention and persistence (Schertzer and Schertzer, 2004). Students' commitment to their academic institution is determined by the degree of academic and social integration such as the participation in university societies and committees and the friendships and acquaintances with fellow students (Tinto, 1975, 1993; Rojas-Méndez et al., 2009).

Relationship commitment is an important issue that influences students' loyalty in tertiary educational institution (Rojas-Méndez et al., 2009; Chen, 2016). The level of relationship commitment is affected by the relationship benefits, shared values, relationship termination costs and trust in the public tertiary education context (Holdford and White, 1997; Adidam et al., 2004). This study adopts Moorman et al.'s (1992) conceptualization of relationship commitment as an enduring desire to maintain a valued relationship.

\section{Relationship Benefits}

Relationship benefits refer to the quality of services and goods relative to other suppliers that have positive influence on relationship commitment, such as continuation of a relationship (Gwinner et al., 1998; Patterson and Smith, 2001). Bitner (1995) identified the benefits to customers of staying in a service relationship including prediction of service quality and comfort, reduction of stress, ignoring switching costs and change. Customers feel comfortable if the relationship is predictable and trust is built. Time and effort in switching to another service provider are saved.

Beatty et al. (1996) categorized social relationship between the customer and sales associate i.e. relationship selling in a retail context that emphasizes the friendship and interaction with the salesperson. Social benefits play an important role on experienced customers' commitment to service provider (Dagger and O'Brien, 2010). Company may benefit from measuring the necessary dimension of the consumers' perceived quality from the company's perspective (Zeithaml et al., 1988).

\section{Relationship between Relationship Benefits and Relationship Commitment}

The business relationship can be affected by the benefits provided by the supplier to the buyer (Jiang et al., 2010). The level of customers' relationship experience in social benefits reflects significant implication on their commitment to service provider (Dagger \& O'Brien, 2010). The relationship marketing concepts can also be applied in the non-profit sector. There are positive impacts between the relationship benefits and the relationship commitment in the non-profit sector (Macmillan et al., 2005). Treating students as partners to the institution and adopting a customer orientation toward students are essential in establishing a sense of mutual relationshipbased commitment (DeShields et al., 2005). 
Adidam et al. (2004) and Holdford and White (1997) examined the impact of relationship benefits on relationship commitment, and concluded that the higher the relationship benefits received by the students, the higher the relationship commitment of students is to their educational institution. Similar conclusions were drawn in the graduates of HKALE in Hong Kong's PTE (Wong and Wong, 2011). This study follows Adidam et al. (2004) and Holdford and White (1997) conceptualization of relationship benefits. Using the aforesaid literature, the first hypothesis is formulated:

\section{H1: Students 'perception of relationship benefits has a significant positive impact on relationship commitment.}

\section{Relationship Termination Costs}

It is common that the "termination costs" and "switching cost" are used interchangeably in research studies. Thus both the termination costs and switching costs are examined in this study.

Termination costs are the expected losses from termination resulted from the perceived lack of potential alternative partners, the expense of relationship dissolution and/or substantial switching costs (Morgan and Hunt, 1994; Chang et al., 2012).

Burnham et al. (2003) classified switching costs as procedural switching costs, financial switching costs and relational switching costs that significantly influence customers' desire to stay or leave their current service provider. Procedural switching costs concern the expense of time and effort. Financial switching costs concern the expense of financial resources, and relational switching costs concern psychological or emotional discomfort because of the loss of identity and the breaking of bonds.

White and Yanamandram (2007) suggested switching costs include uncertainty costs, pre-switching costs, set-up costs, post-switching costs, and benefit/loss costs that are the psychological uncertainty cost in switching to a new service provider (Mitchell, 1999), the time and effort in searching alternatives (Jones et al., 2002), the time and effort in starting the relationship with a new provider (Guiltinan, 1989), adaption to the new provider (Jo nes et al., 2002), the benefit of staying with the current provider (Guiltinan, 1989) and the perceived loss of benefits in terminating the relationship with the current provider (Turnball and Wilson, 1989).

The perceived costs to a student of terminating a relationship with business school might be the loss of friendships developed at school or the risk that course credits at the school might not be accepted at another school (Holdford and Wright,1997). It may cost time and energy to a student to switch to another institution.

\section{Relationship between Relationship Termination Costs and Relationship Commitment}

High perceived switching costs lead to an ongoing current relationship. In addition to economic switching costs, socio-psychological costs such as loss of reputation may also lead to client retention (Dwyer et al., 1987).

Customers' trust and satisfaction vary with the conditions of switching costs, attractiveness of alternatives and client experience. If the perceived economic and psychological costs of developing a new relationship are high, a client will tend to stay with the current relationship (Bansal and Taylor, 1999a, 1999b, Fornell, 1992; Gundlack and Murphy, 1993;Ping, 1993, Sharma and Patterson, 2000; Amani, 2015).

Adidam et al. (2004) examined the relationship between students and their schools and suggested that the relationship termination costs have a positive impact on relationship commitment in the western public tertiary educational institutions. The relationship termination costs are the students' perceived net losses resulting from the termination of the relationship. These include both economic and non-economic sides of switching costs such as loss of friendships or loss of credits on switching to another educational institution. This study adopts conceptualization of relationship termination costs in Porter (1980). Based on the aforesaid literature, the second hypothesis is formulated:

H2: Students' perception of relationship termination costs has a significant positive impact on relationship commitment.

\section{Shared Values}

Different researchers have different interpretation of shared values between parties. Tsai and Ghoshal (1998) defined shared values as a shared code to facilitate a common understanding or perception of collective goals and actions. Shared value leads to more opportunities for the exchange of ideas. In the shared perspective, Levin (2004) examined shared vision and share language while Orr (1990) and Monteverde (1995) examined the shared language and shared narratives. According to social sciences research, sharing information among parties that link people together and establish relationships is considered as shared values (Duncan and Moriarty, 1998; Mohr and Nevin, 1990). 
Morgan and Hunt (1994) defined shared values as "the extent to which partners have beliefs in common about what behaviors, goals and policies are important or unimportant, appropriate or inappropriate, and right or wrong" (Morgan and Hunt, 1994, p.25). Shared value is a key component in building buyer-seller relationships (Wilson 1995; Macmillan et al. 2005; Heffernan et al. 2008). In service industry, similar shared values enhance relationship between the parties (Tsai and Ghoshal, 1998).

\section{Relationship between shared value and relationship commitment}

Having shared values leads to a tertiary level of trust (Coulter and Coulter 2002). In tertiary education, shared values are positively associated with trust (Holdford and White, 1997; Adidam, et al., 2004; Wong and Wong, 2011). As shared values enhance relationship, shared values lead to positive impact on relationship commitment (Holdford and White, 1997; Adidam et al., 2004).

Students would be more likely to commit to a relationship with the institution if they had shared objectives, ideals, codes of conduct, learning methods, and assessments with their educational institution (Holdford and White 1997; Adidam, et al., 2004).

Shared values have positive impact on relationship commitment if they share similar beliefs in behaviors, goals and policies. Having similar values to the educational institution increases graduate trust (Holdford and White 1997; Wong and Wong 2011; Schlesinger et al., 2016). This study adopts the conceptualization of shared values in Morgan and Hunt (1994). Based on the aforesaid literature, the third hypothesis is formulated:

\section{H3: Students'perception of shared values has a significant positive impact on relationship commitment.}

\section{Trust}

Trust is defined as the reliance on the word, promise, oral or written statement by an individual to another or group in the classical studies of psychology, sociology and economics (Rotter, 1967). Different researchers have numerous interpretations of trust in the marketing literature. Many of them consider trust as a kind of belief or confidence on the partner's reliability and integrity and it is the most important dimension that leads to customer loyalty (Morgan and Hunt 1994; Firdaus and Kanyan, 2014).

\section{Relationship between trust and relationship commitment}

Trust is the essential drive for commitment (Dwyer \& Tanner, 2002; Morgan \& Hunt, 1994) since trust leads to returned customers (Berry, 2002). Trust derives from customers' positive experiences that build continuous relationship (Vesel and Zabkar 2010). Dagger and O'Brien (2000) noted that experience over time built between parties results in greater trust (Bove and Johnson, 2000), which leads to commitment to the relationship (Gill et al., 1998). Trust is paired with commitment to building long-term relationship (Firdaus and Kanyan, 2014). A number of empirical studies have revealed that trust has positive impact on customer loyalty (Alrubaiee and Al-Nazer, 2010; Ndubisi, 2007; Aminu, S. A., 2012).

In educational context, trust is students' confidence in the educational institution's integrity and reliability (Rojas-Méndez et al., 2009). Student's trust leads to a positive impact on student's commitment and loyalty to their institution (Perin et al., 2012). Trust is important in retaining current students and attracting new students for tertiary educational institutions (Schlesinger et al., 2016). In this study, trust is conceptualized as the one used by Morgan and Hunt (1994). Based on the abovementioned studies, the fourth hypothesis is formulated:

H4: Students 'trust in the educational institution has a significant positive impact on relationship commitment.

\section{Relationship between Shared Values and Trust}

Shared value is an antecedent to relationship commitment, as well as to trust (Morgan and Hunt, 1994; Mukherjee and Nath, 2007). Higher shared values between partners lead to a higher level of trust (Conner and Backer, 1975). Shared values may facilitate the achievement of common goals, reduce interpersonal barriers and thus lead to trust (Coulter and Coulter, 2002). Customers' shared value is a factor that promotes trust (Wong, 2009).

Shared value is positively related to trust in tertiary education (Holdford and White, 1997; Adidam, et al., 2004; Wong and Wong 2011). Graduates' trust increases when they have similar value perception of the educational institutions (Schlesinger et al., 2016). Based on the abovementioned studies, the fifth hypothesis is formulated:

\section{H5: Students 'perceptions of shared values have a significant positive impact on trust.}

\section{Loyalty}

Customer loyalty captures the long-term relationship between customers and companies, therefore repurchase intent, referral intent and repeated purchases can be resulted, which is regarded as a key to success in business 
(Hart and Johnson, 1999; Bowen and Chen, 2001; Firdaus and Kanyan, 2014).

Loyalty comprises two aspects: repurchase intention and word-of-mouth (Zeithaml et al., 1996). Repurchase intention is a customer's judgement in repurchase a product or services again from the same company (Hellier et al., 2003). Word-of-mouth refers to saying some positive things about the company and recommending the company to others.

\section{Student loyalty in education context}

Student loyalty is crucial in relationship marketing which is a key objective in tertiary education (Hennig-Thurau et al., 2001). Students are regarded as customers (Hennig-Thurau et al., 2001; Brown and Mazzarol, 2009). Building and maintaining student loyalty are similar to customer loyalty, both of which are the essence of marketing (Gulid 2011; Dehghan et al., 2014). Loyalty is a key element in tertiary educational institutions that brings success in a competitive market (Chen, 2016). Trust and commitment have positive impacts on the relationship quality of international students that leads to loyalty to tertiary educational institutions (Bergamo et al. 2012; Chen, 2016).

Tinto (1975, 1993), Hennig-Thurau and Klee (1997), and Hennig-Thurau et al. (2001) suggested that student loyalty is directly affected by perceived service quality and emotional commitment and the antecedents of emotional commitment are academic integration and commitment to non-educational institution activities. Student satisfaction with the programme is a key factor for enhancing student loyalty (Dehghan et al., 2014). Student satisfaction that builds loyalty is also shaped by emotional factors, and institutional image is an important construct for tertiaty students (Brown and Mazzarol 2009; Mihaela, 2012; Schlesinger et al., 2016).

Loyal students are willing to recommend the course or the institution to others, join alumni association and select the institution again for future studies (Hennig-Thurau et al., 2001; Brown and Mazzarol, 2009; Perin et al., 2012). Students' commitment and active participation influence teaching quality (Rodie and Kleine, 2000). With loyal students, educational institutions have the ability to attract new students and retain existing students (Dehghan, 2014).

As gaining new students is more costly than maintaining current students, student retention helps educational institutions in their cost reduction (Reichheld, 1996; Akarapanich, 2006; Dehghan, 2014).

\section{Relationship between Loyalty and Relationship Commitment}

Commitment is a key for achieving customer loyalty that leads to the development of long-term relationships (Anderson and Narus, 1990; Firdaus and Kanyan, 2014). The affective commitment has been studied in the context of relationship marketing extensively (Morgan and Hunt, 1994; Kumar et al., 1995; Gundlach et al., 1995). It is an emotional commitment that reflects a psychological attachment to the partner (Geyskens et al., 1996; Bello and Gilliland, 2002; Verhoef et al, 2002; Sweeney and Swait, 2008). Affective commitment is a crucial variable in developing customer loyalty (Amani, 2015).

Commitment plays positive impact on loyalty (Fournier, 1998; Sheth \& Parvatiyar, 1995) since there are significant interactions between continuance and effective commitment and consumer loyalty (Fullerton, 2003), and such an idea has been applied to academic institutions (Perin et al., 2012). Relationship commitment is an important issue that influences students' loyalty in tertiary education institution (Rojas-Méndez er al., 2009; Chen, 2016). Loyal students can positively influence education quality of the educational institutions through their active participation (Perin et al., 2012). With loyal students, educational institutions have the ability to attract new students and retain existing students (Dehghan et al., 2014). In this study, loyalty is characterized as repurchase intention, and based on the aforesaid literature, the sixth hypothesis is formulated:

H6: Students' relationship commitment to the educational institution has a significant positive impact on student loyalty.

Having reviewed the previous literature and developed the hypotheses for this study, next section will identify the research methodology.

\section{Research Methodology}

This study used questionnaire to collect primary data from students of one of the largest PTE pro viders regarding the relationship between relationship commitment and student loyalty, and the factors affecting relationship commitment. Moreover, students of pilot test also indicated that they were comfortable with filling in the questionnaires. 
The first part of the questionnaire consists of twenty-two questions on the respondents' perceived relationship benefits, relationship termination costs, shared values, trust, relationship commitment and student loyalty towards their educational institution. The second part consists of four questions on the respondents' demographic characteristics. Demographic questions inquire about respondents' gender, age, division of study, and course of study.

This study adopted previously developed and validated measures without substantial alterations. Validated measures of relationship benefits and shared values were taken from two previous studies in education context (Adidam et al., 2004; and Holdford and White, 1997). Regarding relationship termination costs, this study utilized validated measures from Sharma and Patterson (2000). Some wordings were modified to fit the education context. Validated measures of trust and relationship commitment from a previous study in education context (Holdford and White, 1997) were adopted. Validated measures of student loyalty from a previous study in education context (Nguyen and LeBlanc, 2001; Wong and Wong, 2011) were adopted. The scale of the six constructs was operationalized as a 7-point Likert scale from Strongly Disagree to Strongly Agree.

Descriptive statistics, including means, standard deviations, and correlation coefficients among the measures were presented in Table 1. Normally, psychological constructs are often measured with measurement error, leaving the error issues unaddressed results biased estimates of structural relationships. Thus, structural equation modeling (SEM) was employed to examine the proposed mediation model, handling constructs via latent variable approach (Iacobucci, Saldanha \& Deng, 2007). Assessment of model fit was based on multiple criteria, including absolute misfit and incremental fit indices. A model with Root-Mean-Square Errors of Approximation (RMSEA, Steiger \& Lind, 1980) <0.08, Non-Normed Fir Index >0.90 and Comparative Fit Index (CFI, Bentler, 1990) $>0.90$ was considered as having acceptable fit to the data (Hoyle, 1995). All the analyses were conducted using Mplus 7.0 (Muthén \& Muthén, 2011) with maximum likelihood estimation.

\section{Research Anal ysis}

A total of 291 valid responses (126 female, 165 male) were collected in this study. $44.5 \%$ of respondents aged 16 to 18 , and $55.5 \%$ aged 19 to 22 . Most of the students $(91.7 \%)$ were studying associate degree, and there were $8.3 \%$ of tertiary diploma students. More than half of the students $(57.6 \%)$ were from the business division, while $39 \%$ and $3.4 \%$ were from science and technology, as well as communication and social science divisions respectively.

\section{Overall ModelAssessment}

Overall, the mediation model fitted the data well, $\chi^{2}(200)=526.82, \chi^{2} / d f=2.63, p<.001, \mathrm{CFI}=.92, \mathrm{NNFI}=.91$, RMSEA $=.075$ (Table 2). Low $p$-values and relatively high $\chi^{2} / d f$ ratio of a model indicate inadequate fit of the model. However, the Chi-square index is sensitive to sample size; it is not adequately indicative of the extent to which the model does not fit. The larger the sample size is, the tertiary the chance of the model being rejected for fit, whether it is true or false (Bagozzi and Yi, 1988). Relying on Chi-square index alone might cause rejection of a model with a good fit. Therefore, alternative overall fit indices were used: NNFI, CFI, and RMSEA. All fit indices were found to be in an acceptable range, from 0.91 to 0.92 , and the RMSEA of the latent mediation model was 0.075 which was below the minimum requirement of 0.08 . In conclusion, the latent mediation model was considered to fit the data well.

\section{Measurement Model Assessment}

Before investigating structural relations among different constructs, reliability and convergent validity of the constructs were first assessed to ensure the quality of the measured constructs.

\section{Reliability}

Reliability refers to the internal consistency of a set of measurements or measuring instrument. The Cronbach's Alpha is commonly used to measure instrument reliability and its value ranges between 0 and 1 . The closer it is to one, the tertiary is the reliability of the instrument. A commonly accepted rule-of-thumb is that an alpha of 0.6-0.7 indicates acceptable reliability, and 0.8 or tertiary indicates good reliability. In preliminary analyses, alpha coefficients of reliability were estimated by using SPSS version 13.0 for scales from each instrument (Table 3). Reliability coefficients of the six constructs ranged from 0.701 to 0.913 . These statistics show that the measuring instruments used in this study have moderate to high reliability (internal consistency) coefficients for the sample of respondents.

\section{Convergent Validity}

Reliability of a set of measurements or measuring instruments, as measured by alpha coefficient, estimates the 
extent to which there is internal consistency among items (Asubonteng et al., 1996; Bagozzi \& Yi, 1988). Thus, the satisfactory alpha estimates obtained from the reliability test (Table 3 ) demonstrate good convergent validity. Further, the significantly high and moderate loadings of indicators in the measurement model also provided sufficient evidence of convergent validity of the constructs, as shown in Table 4 (Anderson \& Gerbing, 1998; Dabholker, Thorpe \& Rentz, 1996; Patterson et al., 1997). Overall, all factor loadings were statistically significant ( $p s<.001$ ), ranging from .30 to .96 . In addition, the moderate to high correlations between constructs (Table 1) also suggested that measures of the model display a certain degree of convergent validity (Cronin \& Taylor, 1992; Quester \& Romaniuk, 1997).

\section{Structural Model Assessment}

Consistent with the Hypothesis 1 (Table 5), relationship benefits positively predicted relationship commitments, $\beta=.54, p<.001,95 \%$ CIs $[.36, .72]$, which in turn positively predicted student loyalty, $\beta=.41, p<.001,95 \%$ CIs $[.30, .52]$ (Hypothesis 6 ). Taken together, relationship commitments mediated the effect relationship benefits on student loyalty, yielding a significant indirect effect, estimate $=.22, p<.001,95 \%$ Bias-corrected Bootstrap CIs $[.10, .34]$. Contradictory to the expectation, relationship termination costs and shared values did not yield significant prediction to relationship commitments (Hypothesis 2 and 3), $p \mathrm{~s}>.05$. Finally, supporting Hypothesis 4 and 5 , shared values positively predicted trust, $\beta=.73, p<.001,95 \%$ CIs $[.67, .80]$, which in turn positively predicted relationship commitments, $\beta=.16, p=.022,95 \%$ CIs $[.02, .30]$, and then student loyalty. This three-path mediation was qualified by a significant indirect effect, estimate $=.05, p=.028,95 \%$ Bias-corrected Bootstrap CIs $[.003, .10]$, indicating that the effect of shared values on student loyalty worked through trust and relationship commitments. Overall, the predictors explained $63.1 \%$ of total variance in relationship commitments and $16.8 \%$ of total variance in student loyalty. Results of hypotheses testing and structural equation model were shown in Table 5 and Figure 1 respectively.

\section{Perceptual Differences of Constructs across Divisions}

To test perceptual differences of relationship benefits, relationship termination costs, shared values, trust, relationship commitment and student loyalty across divisions (i.e., business, science and technology, as well as communication and social science), six sets of one-way ANOVA were conducted. The results (Table 6) reviewed that significant differences were found on most of the constructs, except on relationship termination costs, across divisions. In general, students in Business division scored highest in all constructs, except in student loyalty and relationship termination costs. For relationship benefits, students in Science and Technology divisions scored in between students in Business division as well as students in Communication and Social Sciences division. For shared values and trust, students in Communication and Social Sciences division scored in between students in Business division as well as students in Science and Technology divisions.

\section{Comparison between HKDSE and HKALE students}

A similar study had been conducted years ago for HKALE students (Wong and Wong, 2011). As mentioned earlier, HKALE students have to take two public examinations before entering tertiary education while HKDSE students just need to take one public examination, and HKALE students are older than HKDSE students in general.

Multiple-group structural equation modelling has been employed to compare the structural parameters in the proposed model across HKDSE ( $N=291$ in current study) and HKALE students ( $N=444$ in previous study). In the structural equation model, factor loadings were constrained as equal across HKDSE and HKALE students, while all other parameters were allowed to freely varied (Figure 2 and 3 ).

Overall, the proposed model has an acceptable fit to data, $\chi^{2}(422)=1372.85, \chi^{2} / d f=3.25, p<.001, \mathrm{CFI}=.91$, $\mathrm{NNFI}=.90, \mathrm{RMSEA}=.078$. Based on the multiple-group analysis, similarities and differences in the strength of the structural parameters can be observed between HKDSE and HKALE students (see Figure 2 and 3). For the commonalities across HKDSE and HKALE students, relationship benefits significantly and positively predicted relationship commitment (comparison estimate $=.348, p=.079$ ), while shared values could not predict relationship commitment (comparison estimate $=.004, p=.985$ ) in both two samples. In addition, shared values positively predicted trust in the same magnitude across two samples (comparison estimate $=.112, p=.226$ ). For the differences across HKDSE and HKALE students, it has been found that relationship termination costs significantly and positively predicted relationship commitment among HKALE students but not HKDSE students (comparison estimate $=-.546, p<.001$ ), while trust significantly and positively predicted relationship commitment among HKDSE students but not HKALE students (comparison estimate $=.245, p=.028$ ). Finally, relationship commitment positively predicted student loyalty in both HKDSE and HKALE students; however, the magnitude of this structural parameter differed across these two samples (comparison estimate $=-.322, p$ 
$<.001)$. Specifically, relationship commitment more strongly predicted student loyalty in HKALE students than in HKDSE students.

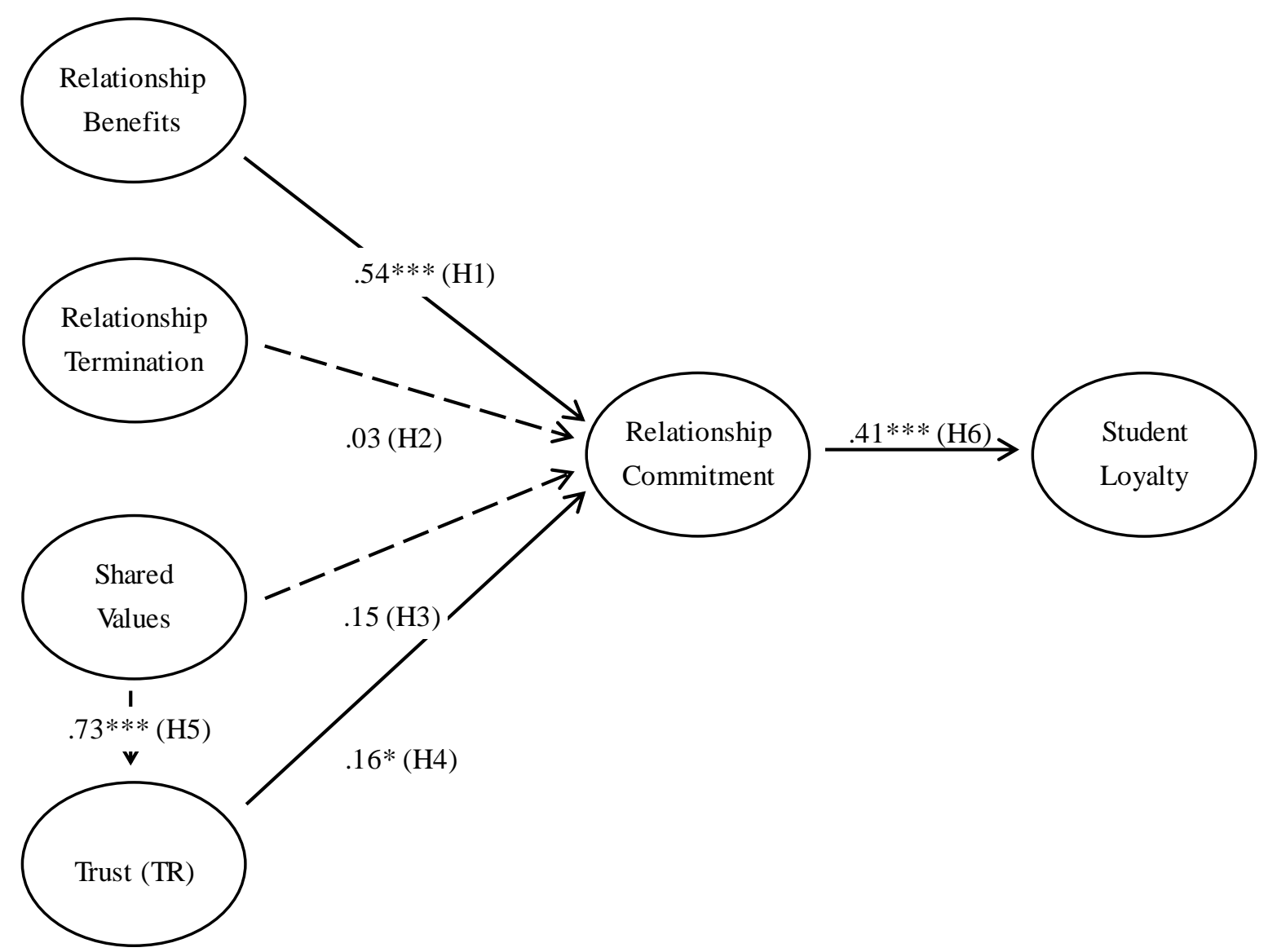

Figure 1. Structural equation model examining mediating effect of relationship commitment of different predictors on student loyalty $(n=291)$

Dashed lines represent non-significant relationships ( $p s>.05)$

$* p<.05 . * * p<.01 . * * * p<.001$.

$$
R_{\mathrm{SL}}^{2}=.168 ; R_{\mathrm{RC}}^{2}=.631 ; R_{\mathrm{TR}}^{2}=.533
$$

Table 1. Means, Standard Deviations, and Intercorrelations for the Measures $(\mathrm{N}=291)$

\begin{tabular}{llccccccc}
\hline & & $M$ & $S D$ & RTC & SV & TR & RC & SL \\
\hline 1. & RB & 5.08 & 0.91 & $.41^{* * *}$ & $.64^{* * *}$ & $.61^{* * *}$ & $.69^{* * *}$ & $.44^{* * *}$ \\
2. & RTC & 4.80 & 0.82 & - & $.45^{* * *}$ & $.39^{* * *}$ & $.38^{* * *}$ & $.29^{* * *}$ \\
3. & SV & 5.08 & 0.88 & - & - & $.64^{* * *}$ & $.62^{* * *}$ & $.41^{* * *}$ \\
4. & TR & 5.43 & 0.88 & - & - & - & $.61^{* * *}$ & $.38^{* * *}$ \\
5. & RC & 4.96 & 1.05 & - & - & - & - & $.49^{* * *}$ \\
6. & SL & 5.13 & 0.97 & - & - & - & - & - \\
\hline
\end{tabular}

Note. $\mathrm{RB}=$ Relationship benefits; $\mathrm{RTC}=$ Relationship termination costs; $\mathrm{SV}=$ Shared values; $\mathrm{TR}=$ Trust $\mathrm{RC}=$ Relationship commitment; $\mathrm{SL}=$ Student loyalty.

$* * * p<.001$.

Table 2. Goodness-of-fit of the Latent Mediation Model

\begin{tabular}{lll}
\hline Fit Indices & Values & Desired Levels* \\
\hline$\chi^{2}$ & 526.82 & -- \\
$D f$ & 200 & - \\
$p$-value & $<.001$ & $>0.05$ \\
$\chi^{2} / d f$ & 2.63 & $<3.0$ \\
Non-Normed fit index (NNFI) & 0.91 & $>0.90$ \\
Comparative fit index (CFI) & 0.92 & $>0.90$ \\
Root-Mean-Square Errors of Approximation (RMSEA) & 0.075 & $<0.08$ \\
\hline
\end{tabular}


Table 3. Reliability of the six constructs

\begin{tabular}{lcc}
\hline & No. of items & Cronbach's Alpha \\
\hline Relationship Benefits & 4 & 0.804 \\
Relationship Termination Costs & 5 & 0.833 \\
Shared Values & 3 & 0.905 \\
Trust & 4 & 0.912 \\
Relationship Commitment & 3 & 0.913 \\
Student Loyalty & 3 & 0.701 \\
\hline
\end{tabular}

Table 4. Results of Factor Loadings in Six Latent Constructs

\begin{tabular}{lc}
\hline Items & Factor \\
loadings
\end{tabular}

Relationship Benefits (RB)

RB1 My college provides several beneficial opportunities for the students, such as exchange programmes, company visits, placements, and professional seminars.

RB2 The location of my college makes this the ideal college to attend.

RB3 The money spent for study in my college is worth it because I can get a bachelor degree offer or I can get a job offer after I finish my study here.

RB4 Overall, my college provides a high quality education.

Relationship Termination Costs (RTC)

RTC1 On the whole, it would cost me a lot of time and energy to find another college to study.

RTC2 I would lose a lot of things if I transfer to another college, such as loss of friendship, and loss of credits.

RTC3 It is risky to change to a new college because the new college may not give what I want.

RTC4 I would feel frustrated if I terminate my study at my college.

RTC5 Considering everything, the costs to terminate my study at my college and start my study at a new college would be high.

\section{Shared Values (SV)}

SV1 My college and I have similar views regarding appropriate behavior in the classroom.

SV2 My college and I have similar views regarding reward structures for good performance in my study.

SV3 My college and I think alike.

\section{Trust (TR)}

$\begin{array}{lr}\text { TR1 My college and lecturers make I feel that my well-being is important. } & .79\end{array}$

$\begin{array}{lr}\text { TR2 My lecturers have high integrity. } & .89\end{array}$

\begin{tabular}{lr} 
TR3 I trust lecturers completely. & .86 \\
\hline
\end{tabular}

$\begin{array}{lr}\text { TR4 My lecturers are always acting in my best interests. } & .87\end{array}$

\section{Relationship Commitment (RC)}

RC1 I feel a strong bond to my college.

RC2 I intend to maintain a relationship with my college after I graduate. $r$

$\begin{array}{ll}\text { RC3 My college deserves the commitment of its students. } & .89\end{array}$

Student Loyalty (SL)

SL1 I would attend degree courses at my college if it offers degree courses in future.

SL2 I would attend the advanced courses at my college if it offers them in the coming years.

SL3 If I had to apply for associate degree or tertiary diploma courses now, my college would be my first $\quad .30$ choices.

\begin{tabular}{|c|c|c|c|c|}
\hline & Construct relationship & $\begin{array}{c}\text { Standardized } \\
\text { coefficients }\end{array}$ & t-value & $\begin{array}{c}\text { Hypothesis } \\
\text { supported }\end{array}$ \\
\hline H1 & RB -> RC & .54 & 4.677 & Yes \\
\hline $\mathrm{H} 2$ & RTC -> RC & .03 & 0.471 & No \\
\hline H3 & SV $\rightarrow$ RC & .15 & 1.309 & No \\
\hline H4 & TR $->$ RC & .16 & 2.302 & Yes \\
\hline H5 & SV $\rightarrow$ TR & .73 & 10.261 & Yes \\
\hline H6 & $\mathrm{RC} \rightarrow \mathrm{SL}$ & .41 & 5.436 & Yes \\
\hline
\end{tabular}

Note. $\mathrm{RB}=$ Relationship benefits; $\mathrm{RTC}=$ Relationship termination costs; $\mathrm{SV}=$ Shared values; $\mathrm{TR}=$ Trust $\mathrm{RC}=$ Relationship commitment; $\mathrm{SL}=$ Student loyalty.

$* * * p<.001$. 
Table 6. One-way ANOVA of each construct by Division of Study

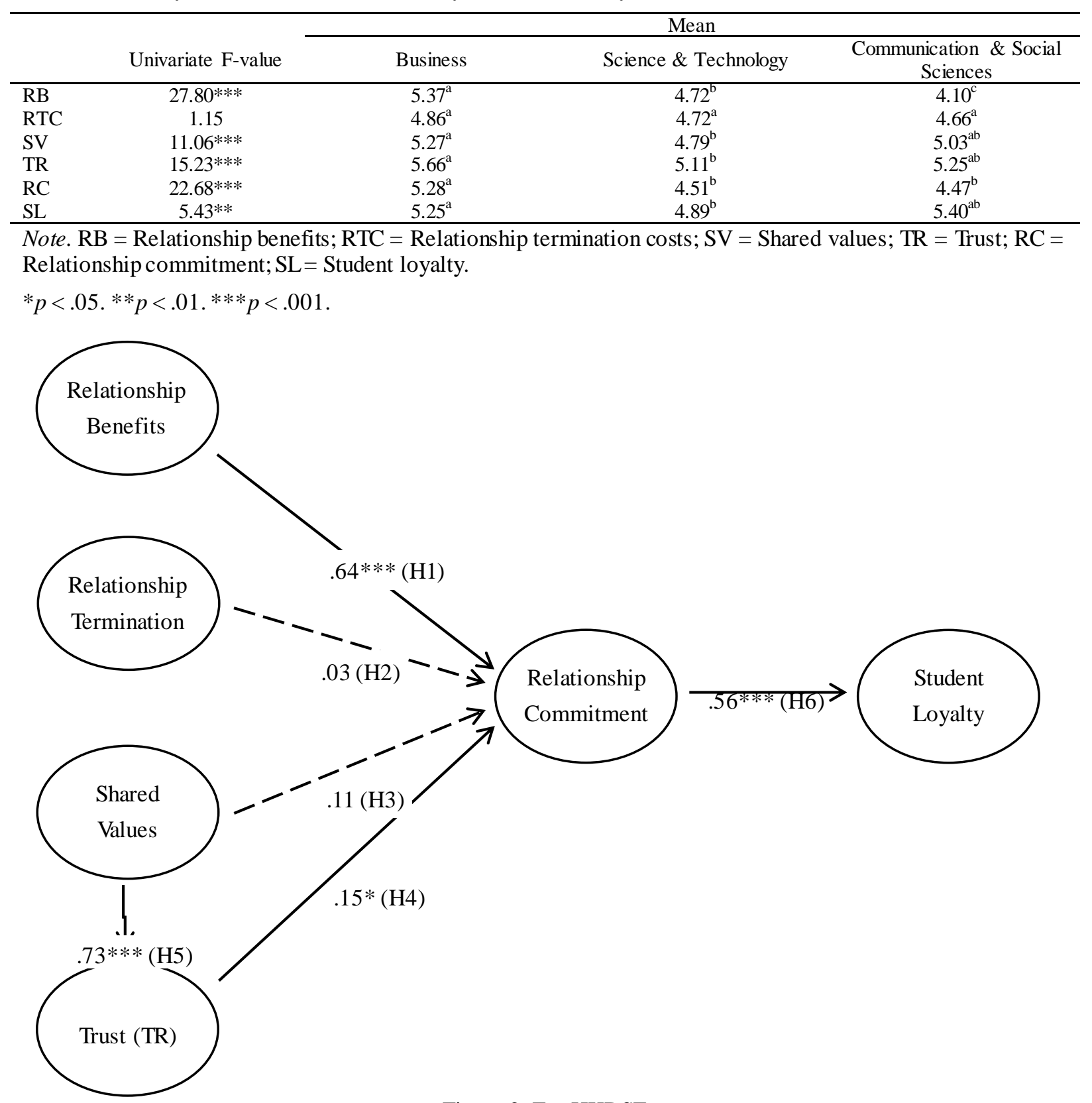

Figure 2. For HKDSE

${ }^{*} p<.05 . * * p<.01 . * * * p<.001$. 


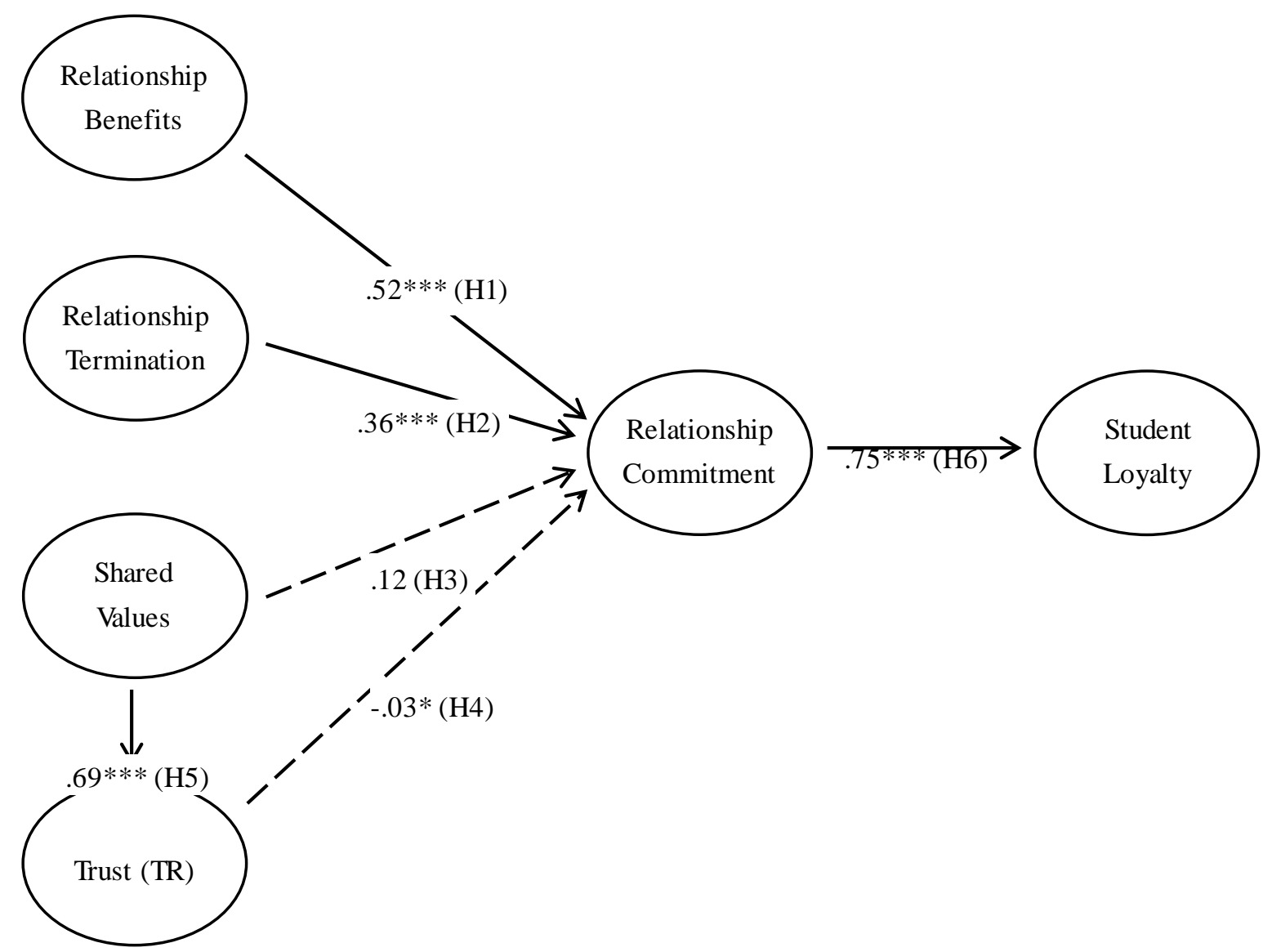

Figure 3. For HKALE

$* \mathrm{p}<.05 . * * \mathrm{p}<.01 . * * * \mathrm{p}<.001$.

\section{Discussions}

The overall structural model is supported by empirical data. Most of the hypothesized relationships are supported. Consistent with many previous studies (Ou et al., 2014; Fullerton, 2014; Caceres and Paparoidamis, 2007; Adidam et al., 2004; Morgan and Hunt, 1994), the result of this study also indicated that there is a positive relationship between relationship commitment and loyalty which was characterized as repurchase intention in this study. Therefore, PTE providers should try to build relationship commitment among students in order to enhance student loyalty.

The finding of this study was also consistent with previous studies (Dagger et al., 2011; Tanford et al., 2010; Adidam et al., 2004; Park and Him, 2003) that relationship benefits characterized as superior quality of services relative to other suppliers have a positive influence on relationship commitment. The construct of relationship benefits is a significant determinant of relationship commitment; PTE providers may consider enhance their benefits provided to students in order to increase students' commitment to schools.

Consistent with previous studies (Afsar et al., 2010; Rodriguez and Wilson, 2002; Morgan and Hunt, 1994), the result of this research indicated that trust is found to have a positive influence on relationship commitment. Trust which was characterized as having confidence in partners' reliability and integrity is a determinant of relationship commitment in this study, howe ver, the positive influence of trust is not as strong as relationship benefits in the PTE context.

Unlike the common findings in relationship marketing literature that relationship termination costs and shared values are determinants of relationship commitment, the direct effects of relationship termination costs and shared values on relationship commitment are found to be insignificant in this study. Relationship termination costs comprised of both economic and non-economic nature in this study; while similar values were characterized as values shared by partners about appropriate behaviors, goals and policies. The result provides new insights to PTE sector. The findings are not surprising because the HKDSE graduates are younger and they are being taken good care by their parents, they do not need to worry too much about economic or non-economic 
issues. Moreover, they care more about whether they have a place to study and not about whether they have similar views or values with schools.

Considering all the four factors (relationship benefits, relationship termination costs, shared values, and trust) affecting relationship commitment, the $\mathrm{R}^{2} 0.631$ indicates that $63.1 \%$ of the variance of relationship commitment is explained by these four factors in the proposed model. However, relationship termination costs and shared values may play non-significant roles in determining relationship commitment in PTE with HKDSE graduates. Among the four factors, private tertiary institutions' students may consider relationship benefits as the most important factor when forming commitment to their schools.

Similar to previous studies (Adidam et al., 2004; Morgan and Hunt, 1994), this research showed that shared values have positive influence on trust. The high $\mathrm{R}^{2} 0.533$ indicates that $53.3 \%$ of the variance of trust is explained by shared values in the proposed model.

\section{Contributions and Future Research}

This research has both theoretical and managerial contributions. The results of this research confirm that relationship commitment has positive influence on loyalty, and relationship benefits and trust have positive influence on relationship commitment, in PTE context with HKDSE graduates. The rejection of predictive effect from relationship termination costs and shared values on relationship commitment in private education sector provides new angle to the application of relationship marketing in eastern education setting.

Education providers have to put a focus on enhancing relationship commitment in order to increase student loyalty. They can also use the results of the path analysis to understand the preferences of their students and allocate resources properly to enhance the factors that affect relationship commitment which, in turn, enhances loyalty. As the result of this study indicates that relationship benefits is the most influential determinants of relationship commitment in PTE industry, education providers should devote more resources to provide better benefits, such as internship and exchange opportunities, professional seminars and workshops, education quality, campus facilities, student activities, to students in order to build relationship commitment. The results also provide insights to different divisions or disciplines for allocating resources in building relationship commitment.

Due to time constraint, a cross-sectional study was conducted, which was difficult to take into account of the actual behavior of respondents. Furthermore, the sample was drawn from only one PTE provider the result might not be able to be generalized for the whole industry. Besides, measurement scales of this study were adopted from previous studies of other contexts, the adopted scales might not be as effective as tailor-made scales for a specific context.

In future, to enhance generalizability of the findings, the study can be extended to other PTE institutions. Longitudinal study can be conducted to have a better understanding of students' actual behavior. Future study can also consider developing measurement scales for education in eastern context which may help management of PTE to have better decision making. If the findings of similar study on HKALE graduates are available, a comparison of the findings between HKALE and HKDSE graduates would be interesting.

\section{References}

Adidam, P. T., Bingi, R. P., \& Sindhav, B. (2004). Building relationships between business schools and students: an empirical investigation into student retention. Journal of College Teaching \& Learning, 1(11), 37-48.

Afsar, B., Rehman, Z. U., Qureshi, J. A., \& Shahjehan, A. (2010). Determinants of customer loyalty in the banking sector: the case of Pakistan. African Journal of Business Management, 4(6), 1040-1047.

Al-Alak, B. A. M. (2006). The impact of marketing actions on relationship quality in the higher education sector in Jordan. Journal of Marketing for Higher Education, 16(2), 1-23. https://doi.org/10.1300/J050v16n02_01

Alrubaiee, L., \& Al - Nazer, N. (2010). Investigate the impact of relationship marketing orientation on customer loyalty: the customer's perspective. International journal of marketing studies, 2(1), 155. https://doi.org/10.5539/ijms.v2n1p155

Amani, Z. (2015). Commitment as a mediator of the relationship between trust and relationship loyalty to retailer. Journal of Business Studies Quarterly, 6(3), 144-163.

Aminu, S. A. (2012). Empirical investigation of the effect of relationship marketing on banks' customer loyalty in Nigeria. Interdisciplinary Journal of Contemporary Research In Business, 4(6), 1249-1266.

Anderson, J. C., \& Gerbing, D. W. (1991). Predicting the performance of measures in a confirmatory factor 
analysis with a pretest assessment of their substantive validities. Journal of Applied Psychology, 76(5), 732. https://doi.org/10.1037/0021-9010.76.5.732

Anderson, J. C., \& Narus, J. A. (1990). A model of distributor firm and manufacturer firm working partnerships. Journal of Marketing, 54(1), 42-58. https://doi.org/10.2307/1252172

Bagozzi, R. P., \& Yi, Y. (1988). On the evaluation of structural equation models. Journal of the Academy of Marketing Science, 16(1), 74-94. https://doi.org/10.1007/BF02723327

Basheer, A. M., \& AL-ALAK (2006) The Impact of Marketing Actions on Relationship Quality in the Higher Education Sector in Jordan, Journal of Marketing for Higher Education, 16(2), 1-23. https://doi.org/10.1300/J050v16n02_01

Beatty, S. E., Mayer, M., Coleman, J. E., Reynolds, K. E., \& Lee, J. (1996). Customer-sales associate retail relationships. Journal of Retailing, 72(3), 223-247. https://doi.org/10.1016/S0022-4359(96)90028-7

Bentler, P. M. (1990). Comparative fit indexes in structural models. Psychological Bulletin, 107, 238-246. https://doi.org/10.1037/0033-2909.107.2.238

Berry, L. L. (1995). Relationship marketing of services-growing interest, emerging perspectives. Journal of the Academy of Marketing Science, 23(4), 236-245. https://doi.org/10.1177/009207039502300402

Bitner, M. (1995). Building service relationships: it's all about promises. Journal of the Academy of Marketing Science, 23(4), 246-251. https://doi.org/10.1177/009207039502300403

Bove, L. L., \& Johnson, L. W. (2000), A customer-service worker relationship model. International Journal of Service Industry Management, 11(5), 491-511. https://doi.org/10.1108/09564230010360191

Brown, R. M., \& Mazzarol, T. W. (2009). The importance of institutional image to student satisfaction and loyalty within higher education. The International Journal of Higher Education and Educational Planning, 58(1), 81-95. https://doi.org/10.1007/s10734-008-9183-8

Burnham, T., Frels, J., \& Mahajan, V. (2003). Consumer switching costs: A typology, antecedents, and consequences. Journal of the Academy of Marketing Science, 31(2), 109-126. https://doi.org/10.1177/0092070302250897

Caceres, R. C., \& Paparoidamis, N. G. (2007). Service quality, relationship satisfaction, trust, commitment and business-to-business loyalty. European Journal of Marketing, $41(7$ \& 8), 836-867. https://doi.org/10.1108/03090560710752429

Carvalho, S. W., \& De Oliveira, M. M. (2010). The role of trust in creating value and student loyalty in relational exchanges between higher education institutions and their students. Journal of Marketing for Higher Education, 20(1), 145-165. https://doi.org/10.1080/08841241003788201

Chang, S. H., Wang, K. Y., Chih, W. H., \& Tsai, W. H. (2012). Building customer commitment in business-to-business markets. Industrial Marketing Management, 41 (6), 940-950. https://doi.org/10.1016/j.indmarman.2011.11.026

Chen, Y. C. (2016). The Drive behind international student loyalty in higher-educational institutions: a structural equation model. The Asia-Pacific Education Researcher, 25(2), 315-323. https://doi.org/10.1007/s40299-015-0264-z

Cronin, J. J. J., \& Taylor, S. A. (1992). Measuring service quality: a reexamination and extension. The Journal of Marketing, 55-68. https://doi.org/10.2307/1252296

Dabholkar, P. A., Thorpe, D. I., \& Rentz, J. O. (1995). A measure of service quality for retail stores: scale development and validation. Journal of the Academy of Marketing Science,24(1), 3-16. https://doi.org/10.1177/009207039602400101

Dagger, T. S., \& O'Brien, T. K. (2010). Does experience matter? differences in relationship benefits, satisfaction, trust, commitment and loyalty for novice and experienced service users. European Journal of Marketing, 44(9/10), 1528-1552. https://doi.org/10.1108/03090561011062952

Dagger, T. S., David, M. E., \& Ng, S. (2011). Do relationship benefits and maintenance drive commitment and loyalty? Journal of Services Marketing, 25(4), 273-281. https://doi.org/10.1108/08876041111143104

Dehghan, A., Dugger, J., Dobrzykowski, D., \& Balazs, A. (2014). The antecedents of student loyalty in online programs. International Journal of Educational Management, 28(1), 15-35.

https://doi.org/10.1108/IJEM-01-2013-0007 
DeShields, O. W., Kara, A., \& Kaynak, E. (2005). Determinants of business student satisfaction and retention in higher education: applying Herzberg's two factor theory. International Journal of Educational Management, 19(2), 128-139. https://doi.org/10.1108/09513540510582426

Dwyer, F. R., Schurr, P. H., \& Oh, S. (1987). Developing buyer-seller relationships. Journal of Marketing, 51 (2), 11-17. https://doi.org/10.2307/1251126

Finch, D., O'Reilly, N., Hillenbrand, C., \& Abeza, G. (2015). Standing on the shoulders of giants: an examination of the interdisciplinary foundation of relationship marketing. Journal of Relationship Marketing, 14(3), 171-196. https://doi.org/10.1080/15332667.2015.1069525

Firdaus, A., \& Kanyan, A. (2014). Managing relationship marketing in the food service industry. Marketing Intelligence \& Planning, 32(3), 293-310. https://doi.org/10.1108/MIP-10-2012-0116

Fullerton, G. (2014). The moderating effect of normative commitment on the service quality-customer retention relationship. European Journal of Marketing, 48(3/4), 657-673. https://doi.org/10.1108/EJM-06-2011-0333

Geyskens, I., Steenkamp, J., Scheer, L., \& Kumar, N. (1996). The effects of trust and interdependence on relationship commitment: a transatlantic study. International Journal of Research in Marketing, 13(4), 303-317. https://doi.org/10.1016/S0167-8116(96)00006-7

Grönroos, C. (1994). From Marketing Mix to Relationship Marketing. Management Decision, 32 (2), 4-20. https://doi.org/10.1108/00251749410054774

Harker, M. J. (1999). Relationship marketing defined? an examination of current relationship marketing definitions. Marketing Intelligence \& Planning, 17(1), 13-20. https://doi.org/10.1108/02634509910253768

Hart, C. W., \& Johnson, M. D. (1999). Growing the trust relationship. Marketing Management, 8(1), 8-19.

Helena, A., \& Mário, R. (2010). The influence of university image on student behaviour. International Journal of Educational Management, 24(1), 73-85. https://doi.org/10.1108/09513541011013060

Hennig-Thurau, T., Langer, M. F., \& Hansen, U. (2001). Modeling and managing student loyalty: an approach based on the concept of relationship quality. Journal of Service Research, 3(4), 331. https://doi.org/10.1177/109467050134006

Holdford, D., \& White, S. (1997). Testing commitment-trust theory in relationships between pharmacy schools and students. American Journal of Pharmaceutical Education, 61(Fall), 249-256.

Hoyle, R. H. (Ed.). (1995). Structural equation modeling: Concepts, issues, and applications . Sage Publications.

Iacobucci, D., Saldanha, N., \& Deng, X. (2007). A meditation on mediation: Evidence that structural equations models perform better than regressions. Journal of Consumer Psychology,17(2), 139-153. https://doi.org/10.1016/S1057-7408(07)70020-7

Jagdish, N. S. (2002). The future of relationship marketing. Journal of Services Marketing, 16(7), 590-592. https://doi.org/10.1108/08876040210447324

Levin, D. Z. (2004). Perceived trustworthiness of knowledge sources: The moderating impact of relationship length. Journal of Applied Psychology. https://doi.org/10.5465/AMBPP.2004.13862408

Macmillan, K., Money, K., Money, A., \& Downing, S. (2005). Relationship marketing in the not-for-profit sector: an extension and application of the commitment-trust theory. Journal of Business Research, 58(6), 806-818. https://doi.org/10.1016/j.jbusres.2003.08.008

Mihaela, B. A. (2012). Analysis of marketing tools and activities within educational services organizations, in order to increase their efficiency. Annals of the University of Oradea : Economic Science, 1(1), 1106-1111.

Min, S., \& Khoon, C. C. (2014). Demographic factors in the evaluation of service quality in higher education: a Structural Equation Model (SEM) Approach. International Journal of Marketing Studies, 6(1). https://doi.org/10.5539/ijms.v6n1p90

Miquel-Romero, M. J., Caplliure-Giner, E. M., \& Adame-Sánchez, C. (2014). Relationship marketing management: its importance in private label extension. Journal of Business Research, 67(5), 667-672. https://doi.org/10.1016/j.jbusres.2013.11.025

Monteverde, K. (1995). Technical dialog as an incentive for vertical integration in the semiconductor industry. Management Science, 41(10), 1624-1638. https://doi.org/10.1287/mnsc.41.10.1624

Moorman, C., Zaltman, G., \& Deshpande, R., (1992). Relationships between providers and users of marketing 
research: the dynamics of trust within and between organizations. Journal of Marketing Research, 29(3), 314-329. https://doi.org/10.2307/3172742

Morgan, R., \& Hunt, S. (1994). The commitment-trust theory of relationship marketing. Journal of Marketing, 58, 20-38. https://doi.org/10.2307/1252308

Mukherjee, A., \& Nath, P. (2007). Role of electronic trust in online retailing: a re-examination of the Commitment-Trust theory. European Journal of Marketing, 41(9/10), 1173-1202. https://doi.org/10.1108/03090560710773390

Muthén L. K., \& Muthén B. O. (2011). Mplus user's guide (6 ${ }^{\text {th }}$ ed.). Los Angeles, CA: Author.

Nguyen, N., \& LeBlanc, G. (2001). Image and reputation of higher education institutions in students' retention decisions. The International Journal of Educational Management, 15(6), 303-311. https://doi.org/10.1108/EUM0000000005909

Orr, J. E. (1990). Sharing knowledge, celebrating identity: Community memory in a service culture. In Middleton D., and Edwards D (Ed.). Collective Remembering, Sage, London, 169-189.

Ou, W. M., Shih, C. M., \& Chen, C. Y. (2014). Antecedents and consequences of relationship commitment: an empirical study in Taiwan. International Journal of Commerce and Management, 24(3), 228-242. https://doi.org/10.1108/IJCoMA-05-2012-0033

Øyvind, H. (2008). Marketing for higher education: a relationship marketing approach. Journal of Marketing for Higher Education, 18(1), 50-78. https://doi.org/10.1080/08841240802100188

Park, C. H., \& Kim, Y. G. (2003). Identifying key factors affecting consumer purchase behavior in an online shopping context. International Journal of Retail and Distribution Management, 31(1), 16-29. https://doi.org/10.1108/09590550310457818

Perin, M. G., Sampaio, C. H., Simões, C., \& De Pólvora, R. P. (2012). Modeling antecedents of student loyalty in higher education. Journal of Marketing for Higher Education, 22(1), 101-116. https://doi.org/10.1080/08841241.2012.705797

Quester, P., \& Romaniuk, S. (1997). Service quality in the Australian advertising industry: a methodological study. Journal of Services Marketing, 11(3), 180-192. https://doi.org/10.1108/08876049710168672

Reichheld, F. F. (1996). The Loyalty Effect, Boston: Harvard Business School Press.

Rodriguez, C. M., \& Wilson, D. T. (2002). Relationship bonding and trust as a foundation for commitment in U.S. - Mexican Strategic Alliances: a structural equation modelling approach. Journal of International Marketing, 10(4), 53-76. https://doi.org/10.1509/jimk.10.4.53.19553

Rojas-Méndez, J., Vasquez-Parraga, A., Kara, A., \& Cerda-Urrutia, A. (2009). Determinants of student loyalty in higher education: a tested relationship approach in latin America. Latin American Business Review, 10(1), 21-39. https://doi.org/10.1080/10978520903022089

Rotter, J. B. (1967). A new scale for the measurement of interpersonal trust. Journal of Personality, 35(4), 651-665. https://doi.org/10.1111/j.1467-6494.1967.tb01454.x

Schlesinger, W., Cervera, A., \& Pérez-Cabañero, C. (2016). Sticking with your university: the importance of satisfaction, trust, image, and shared values. Studies in Higher Education, 04 February 2016, 1-17.

Sharma, N., \& Patterson, P. G. (2000). Switching costs, alternative attractiveness and experience as moderators of relationship commitment in professional, consumer services. International Journal of Service Industry Management, 11(5), 470-490. https://doi.org/10.1108/09564230010360182

Steiger, J. H., \& Lind, J. C. (1980). Statistically based tests for the number of common factors. Paper presented at the Psychometric Society Annual Meeting, Iowa City, IA.

Tanford, S., Raab, C., \& Kim, Y. S. (2010). The influence of reward program membership and commitment on hotel loyalty. Journal of Hospitality \& Tourism Research, 1-29.

Tinto, V. (1975). Dropout from higher education: a theoretical synthesis of recent research. Review of Educational Research, 45(1), 89-125. https://doi.org/10.3102/00346543045001089

Tracey, S. D., \& Timothy, K. O. (2010). Does experience matter? differences in relationship benefits, satisfaction, trust, commitment and loyalty for novice and experienced service users. European Journal of Marketing, 44(9/10), 1528-1552. https://doi.org/10.1108/03090561011062952 
Tsai, W., \& Ghoshal, S. (1998). Social Capital and Value Creation: the Role of Intrafirm Networks. Academy of Management Journal, 41 (4), 464-476. https://doi.org/10.2307/257085

Wang, J. S. (2009). Trust and relationship commitment between direct selling distributors and customers, African Journal of Business Management, 3(12), 862-870.

White, L., \& Yanamandram, V. (2007). A model of customer retention of dissatisfied business services customers. Managing Service Quality: An International Journal, 17(3), 298-316. https://doi.org/10.1108/09604520710744317

Wong, A., \& Sohal, A. (2002). An examination of the relationship between trust, commitment and relationship quality. International Journal of Retail \& Distribution Management, 30(1), 34-50. https://doi.org/10.1108/09590550210415248

Wong, H., \& Wong, K. H. (2011). Building Relationship between education institutions and students: Student Loyalty in self-financed tertiary education. IBIMA Business Review, 2011 (913652), 1-31.

Wu, M. Y., Weng, Y. C., \& Huang, I. C. (2012). A study of supply chain partnerships based on the commitment-trust theory. Asia Pacific Journal of Marketing and Logistics, 24(4), 690-707. https://doi.org/10.1108/13555851211259098

Zeithaml, V., Berry, L. L., \& Parasuraman, A. (1996). The behavioral consequences of service quality. Journal of Marketing, 60(2), 31. https://doi.org/10.2307/1251929

Zhizhong, J., Stephan, C., \& Henneberg, P. N. (2010). Exploring trust vis-à-vis reliance in business relationships: a qualitative analysis in the UK construction industry. Marketing Intelligence \& Planning, 28(6), 706-722. https://doi.org/10.1108/02634501011078110

Website:

EDB - Education Bureau (http://www.edb.gov.hk/en/)

iPASS - Information Portal for Accredited Post-secondary Programmes "iPASS" (http://www.ipass.gov.hk/)

\section{Copyrights}

Copyright for this article is retained by the author(s), with first publication rights granted to the journal.

This is an open-access article distributed under the terms and conditions of the Creative Commons Attribution license (http://creativecommons.org/licenses/by/4.0/). 